Bidang ilmu: Keperawatan

\title{
HUBUNGAN POLA MP-ASI TERHADAP STATUS GIZI ANAK DI PUSKESMAS SURADITA KAB.TANGERANG
}

\author{
Hanifah Eka Cahyaningsih1), Rokhaidah2) \\ Fakultas Ilmu Kesehatan ${ }^{1,2}$ \\ Universitas Pembangunan Nasional Veteran Jakarta \\ hanifahekac@upnvj.ac.id1); rokhaidah@upnvj.ac.id²)
}

\begin{abstract}
ABSTRAK
Makanan pendamping air susu ibu (MP-ASI) diberikan saat anak sudah berusia 6 bulan, fungsi MP-ASI sendiri untuk melengkapi kebutuhan nutrisi dari ASI. WHO merekomendasikan pemberian MP-ASI yang baik dan bernutrisi, dengan mengkategorikannya menurut usia, tesktur, jumlah dan frekuensi. Penelitian ini bertujuan untuk menganalisis hubungan pola pemberian makanan pendamping air susu ibu (MP-ASI) terhadap status gizi anak di Wilayah Kerja Puskesmas Suradita Kabupaten Tangerang. Penelitian ini menggunakan desain penelitian Cross Sectional dan dilakukan pada 90 sampel melalui metode purposive sampling. Pengumpulan data menggunakan kuesioner pola pemberian MP-ASI yang telah dilakukan uji validitas dan reliabilitas. Hasil uji statistik dengan Confident interval sebesar 95\% menunjukan hasil p-value sebesar 0,007 yang berarti terdapat hubungan yang bermakna antara pola pemberian MP-ASI terhadap status gizi dan nilai odds ratio (OR) sebesar 4,960 yang berarti anak yang diberikan pola MP-ASI tepat beresiko 4,960 kali berstatus gizi normal dibandingkan dengan anak yang diberikan pola MP-ASI tidak tepat. Peneliti menyarankan pada penelitian selanjutnya untuk mengukur juga banyak energi yang dikonsumsi oleh anak, agar pengukur pola MP-ASI menjadi lebih spesifik.
\end{abstract}

Kata kunci: Anak; Gizi; MP-ASI; Pola

\begin{abstract}
Complementary feeding (MP-ASI) is given when the child is 6 months old, the function of MP-ASI itself is to supplement the nutritional needs of breast milk. WHO recommends giving good and nutritious MP-ASI, by categorizing it according to age, texture, number and frequency. This study aims to analyze the relationship of complementary feeding patterns (MP-ASI) with the nutritional status of children in the Suradita Community Health Center in Tangerang Regency. This study used a cross sectional design with 90 participants through a purposive sampling method. Data collection used questionnaire pattern of giving MP-ASI which has been tested for validity and reliability. Statistical test results with $95 \%$ confidence intervals indicate that a p-value of 0.007 means that there is a significant relationship between the pattern of giving MP-ASI and nutritional status with an odds ratio (OR) of 4.960 which means that children given with a correct MP-ASI pattern is 4,960 times have higher chance of having a normal nutritional status compared to children who are not given a correct MP-ASI pattern. Researcher suggest in subsequent studies to measure the energy consumed by children to be able to measure MP-ASI pattern more specific Researchers suggest in subsequent studies to measure also a lot of energy consumed by children, so that the measurement of the MP-ASI pattern becomes more specific.
\end{abstract}

Keywords: Child; Complementary Feeding; Nutritional; Patterns

Alamat korespondensi: Cisauk, Kabupaten Tangerang 
Email: hanifahekac@upnvj.ac.id

Nomor Hp: 085885895377

\section{PENDAHULUAN}

Kementerian Kesehatan (Kemenkes RI) membuat rancangan Rencana Pembangunan Jangka Panjang Nasional (RPJPN) untuk 20 tahun kedepan, yang dimulai sejak tahun 2005 yang memprioritaskan program kesehatan ibu dan anak (KIA). Sunarsih \& Shanti (2019) menjelaskan bahwa gizi yang mencukupi merupakan faktor yang mampu menurunkan jumlah kematian ibu dan anak. Padahal, pada tahun awal kehidupan anak merupakan masa yang krusial, karena pemenuhan gizi yang baik pada masa ini dapat menurunkan angka kematian dan kesakitan, mengurangi terjadinya penyakit kronis, dan berpengaruh pada tumbuh kembang anak. World health organization (WHO) menjelaskan bahwa menyusui dengan optimal dapat menyelamatkan lebih dari 820.000 nyawa balita pertahunnya (WHO, 2018).

WHO mengklasifikasi dua pola pemberian ASI pada anak, yaitu eksklusif dan non eksklusif. Menyusui eksklusif yaitu hanya memberikan ASI saja kepada anak. Menyusui non-eksklusif dibagi menjadi dua yaitu menyusui predominan adalah menyusui serta memberikan minuman selain ASI dan menyusui parsial adalah menyusui serta memberikan makanan tambahan (Subdanra, Zuhairini dan Djais, 2018). Berdasarkan rekomendasi WHO dan United Nation Children Fund (UNICEF) anak-anak harus disusui pada jam pertama kelahiran atau inisiasi menyusui dini (IMD) dan disusui eksklusif sampai usia 6 bulan - yang berarti tidak diberi makanan atau cairan lain yang diberikan. Memasuki usia 6 bulan, anak sudah mulai diperkenalkan dengan MP-ASI (makanan pendamping ASI) atau tambahan makanan yang aman dan memadai juga harus terus disusui hingga 2 tahun ke atas (WHO, 2020).

Makanan pendamping ASI (MP-ASI) adalah makanan pelengkap ASI, ketika anak membutuhkan kebutuhan gizi yang lebih dari ASI (Zogara, 2020). Pada saat usia 6 bulan, secara fisiologis fungsi saluran cerna anak sudah siap untuk menerima MP-ASI dan pada usia tersebut nutrisi dari ASI tidak mampu memadai untuk kebutuhan nutrisi maupun gizi pada anak (Damayanti dan Fatonah, 2016). Widiastuti, dkk (2018) berpikiran bahwa pemberian MP-ASI yang tidak tepat pada usia 6 bulan dapat menimbulkan beberapa dampak yaitu berkurangnya pemberian ASI, obesitas dan terhambatnya pertubuhan anak. Pusat Penelitian dan Pengembangan Gizi dan Makanan menemukan bahwa pemberian MP-ASI tidak tepat usia dapat meningkatkan risiko timbulnya infeksi saluran pencernaan dan pernafasan (Heryanto, 2017). Selain itu pola pengasuhan ibu dan pola makan anak yang tidak sesuai usia juga dapat menjadi penyebab masalah gizi pada anak (Sagala, 2018), hal tersebut dikarenakan kuantitas nutrisi tidak dapat mencukupi atau melebihi kebutuhan gizi anak, sehingga dapat menyebabkan anak mengalami gizi kurang atau gizi berlebih (Damayanti dan Fatonah, 2016).

Pemerintah telah berupaya memberikan edukasi melalui program pendidikan kesehatan terkait fungsi serta manfaat dari asi eksklusif bagi balita, melalui penyebaran informasi, pelatihan cara menyusui bagi para ibu, penyediaan sarana ruang menyusui di tempat umum dan pemberdayaan masyarakat untuk meningkatkan peran serta suami dan keluarga dalam pemberian ASI eksklusif (Maria, 2016). WHO juga merekomendasikan dan memberikan paduan dalam pemberian MP-ASI untuk anak usia 6 bulan keatas. Pemberian pada setiap usia anak berbeda-beda jumlah, frekuensi dan tekstur yang harus diberikan (IDAI, 2018).

Rekomendasi WHO tentang MP-ASI yang baik yaitu, memberikan makanan yang mudah dan terjangkau akan tetapi kaya energi, protein, dan mikronutrein. Panduan MP-ASI tersebut dikenal dengan prinsip AFATVAH (Age, Frequency, Amount, Texture, Variety, Active/Responsive, Hygiene). Terdiri dari menu Tunggal dan 4 Bintang. Makanan 4 bintang yaitu makanan yang dibuat dengan memasukan kategori makanan pokok, sayuran dan buah, kacang- kacangan dan makanan hewani (Saputri dan Kusumastuti, 2019). WHO dan pemerintah telah melakukan banyak upaya untuk memperbaiki status gizi anak, tetapi sampai sekarang masih terdapat anak dengan masalah gizi 
kurang, hal ini dikarenakan pemenuhan ASI dan MP-ASI yang tidak seimbang kebutuhan gizi anak (Waliyo, Marlenywati dan Nurseha, 2017).

Berdasarkan wawancara yang dilakukan pada 10 orang ibu di posyandu desa Suradita, hanya satu orang ibu yang memberikan MP-ASI sesuai pola pemberian yang dianjurkan WHO sesuai usia anaknya. Hasil wawancara tersebut membuktikan bahwa masih belum optimalnya upaya pemerintah mengenai pemberian MP-ASI kepada masyarakat, karena masih banyak di temukan masyarakat yang memberikan MP-ASI tidak tepat. Berdasarkan fenomena tersebut maka penelitian ini bertujuan menganalisis hubungan pola pemberian makanan pendamping air susu ibu (MP-ASI) terhadap status gizi anak di Wilayah Kerja Puskesmas Suradita Kabupaten Tangerang.

\section{METODE PENELITIAN}

Desain penelitian ini ialah analitik dengan menggunakan pendekatan crossectional. Sampel pada penelitian ini ialah ibu dengan anak usia antara 6-24 bulan dari 3 posyandu di Wilayah Kerja Puskesmas Suradita sebanyak 90 responden, dengan menggunakan teknik pengambilan sampel yaitu nonprobability sampling dengan metode purposive sampling.

Instrumen penelitian yang digunakan pada penelitian ini berupa kuesioner atau pertanyaan mengenai data demografi, pemberian ASI dan pola pemberian MP-ASI yang telah diuji validitas dan reliabilitas dengan jumlah pertanyaan sebanyak 9 pertanyaan.

\section{HASIL DAN PEMBAHASAN}

Tabel 1 Distribusi Rata-Rata Usia Responden di Desa Suradita $(\mathrm{n}=81)$

\begin{tabular}{ccccc}
\hline Variabel & Mean & Median & Standar Deviasi & n \\
& & & & \\
\hline Usia Ibu & 32,01 & 32,00 & 6,457 & 81 \\
Usia Anak & 15,42 & 16,00 & 5,873 & 81 \\
\hline
\end{tabular}

Berdasarkan tabel 1, dari 81 responden mayoritas anak dengan ibu berusia antara 18 sampai 46 tahun dan rata-rata usia ibu 32,01 tahun dan mayoritas anak usia 6-24 bulan dengan rata-rata usia 15,42 bulan. Usia 32 tahun termasuk dalam usia dewasa tengah, usia ini merupakan usia wanita produktif. Kategori usia wanita produktif yaitu diantara usia 20 - 35 tahun, periode ini merupakan periode reproduksi, saat ini seorang wanita sudah dapat berpikir secara dewasa dan dapat mengambil keputusan dengan tengan, terutama menyangkut kehamilan dan merawat anak serta memperhatikan gizi anak (Maria, 2016). Usia 15 bulan termasuk dalam periode 1000 hari pertama kehidupan, periode ini biasa disebut dengan periode emas atau periode kritis. Saat usia 024 bulan anak harus diberikan nutrisi yang cukup sehingga periode ini akan menjadi periode emas, sebaliknya pemberian nutrisi yang kurang akan menyebabkan periode ini menjadi periode kritis dan akan berpengaruh dengan tumbuh kembang anak (Yuliarti, 2010).

Tabel 2 Distribusi Frekuensi Pendidikan Orang Tua Responden di Desa Suradita (n=81)

\begin{tabular}{ccc}
\hline Pendidikan & n & $\%$ \\
\hline Rendah & 22 & 27,2 \\
Menengah & 46 & 56,8 \\
Tinggi & 13 & 16 \\
Total & 81 & 100 \\
\hline
\end{tabular}

Berdasarkan tabel 2, dari 81 responden mayoritas anak dari ibu berpendidikan menengah (SMA/SMK) yaitu 46 (56,8\%). Sejalan dengan penelitian Prita Swandari, sebagian besar ibu berpendikan SMA sejumlah 49 (61,2\%). Pendidikan ibu mempengaruhi status gizi anak, karena ibu berpendidikan tinggi akan lebih mampu menyerap informasi mengenai nutrisi dan gizi baik bagi anak dan keluarganya (Swdanari dkk., 2017). 
Tabel 3 Distribusi Frekuensi Jenis Kelamin Anak di Desa Suradita ( $\mathrm{n}=81)$

\begin{tabular}{ccc}
\hline Jenis Kelamin & $\mathbf{n}$ & $\mathbf{\%}$ \\
\hline Laki-laki & 37 & 45,7 \\
Perempuan & 44 & 54,3 \\
Total & 81 & 100
\end{tabular}

Berdasarkan tabel 3 menunjukan dari 81 responden sebagian besar anak 6-24 bulan berjenis kelamin perempuan yaitu 44 (54,3\%). Sesuai dengen penelitian Bella Hayyu yaitu mayoritas responden berjenis kelamin perempuan. Adriani dan Wirjatmadi (2014) mengatakan kebutuhan gizi anak perempuan dan laki-laki tidak sama. Kebutuhan energi dan protein pada anak perempuan lebih sedikit dibanding anak laki-laki.

Tabel 4 Distribusi Pemberian ASI Responden di Desa Sampora $(n=81)$

\begin{tabular}{|c|c|c|c|}
\hline \multicolumn{2}{|c|}{ ASI } & $\mathbf{n}$ & $\%$ \\
\hline \multirow{2}{*}{ ASI eksklusif } & $\mathrm{Ya}$ & 77 & 95,1 \\
\hline & Tidak & 4 & 4,9 \\
\hline \multirow{2}{*}{$\begin{array}{l}\text { Pemberian } \\
\text { ASI saat ini }\end{array}$} & $\mathrm{Ya}$ & 57 & 70,4 \\
\hline & Tidak & 24 & 29,6 \\
\hline \multirow{3}{*}{$\begin{array}{c}\text { Waktu } \\
\text { pemberian } \\
\text { ASI }\end{array}$} & $\begin{array}{l}\text { Sebelum } \\
\text { MP-ASI }\end{array}$ & 26 & 32,1 \\
\hline & $\begin{array}{l}\text { Sesudah } \\
\text { MP-ASI }\end{array}$ & 31 & 38,3 \\
\hline & $\begin{array}{c}\text { Susu } \\
\text { Formula }\end{array}$ & 24 & 29,6 \\
\hline
\end{tabular}

Berdasarkan tabel 4 menunjukan dari 81 responden dominan diberikan ASI eksklusif yaitu 77 $(95,1 \%)$, masih diberikan ASI sampai saat ini yaitu $57(70,4 \%)$ dan memberikan ASI sesudah diberikan MP-ASI yaitu 31 (38,3\%). Sejalan dengan penelitian Iis Maria, sebagian besar anak diberikan ASI eksklusif sejumlah 19 (55,9\%). Menurut Maria (2016) anak yang tidak diberi ASI eksklusif disebabkan kurangnya pengetahuan ibu, jika pengetahuan ibu baik mengenai pemberian ASI, maka ibu akan lebih mempertimbangkan untuk memberika ASI eksklusif pada bayinya.

Pemberian ASI sudah tidak mampu memenuhi nutrisi pada anak 6 bulan, sehingga anak memerlukan nutrisi tambahan dari MP-ASI (Damayanti dan Fatonah, 2016). Pemberian MP-ASI berfungsi untuk melengkapi nutrisi dari ASI bukan sebagai pengganti ASI, maka pemberian ASI sangat dianjurkan sampai anak berusia 24 bulan (Widiastuti ,dkk., 2018). Ismawati (2020) berpendapat pemberian ASI akan lebih baik diberikan sebelum pemberian MP-ASI, dengan begitu ibu dapat mengetahui jika anak sudah merasa kenyang, sehingga pemberian ASI dan MP-ASI menjadi lebih seimbang.

Tabel 5 Distribusi Pola MP-ASI Responden di Desa Suradita $(\mathrm{n}=81)$

\begin{tabular}{ccc}
\hline Pola MP-ASI & $\mathbf{n}$ & $\%$ \\
\hline Tepat & 36 & 44,4 \\
Tidak Tepat & 45 & 55,6 \\
Total & 81 & 100
\end{tabular}

Berdasarkan tabel 5, dari 81 anak usia 6-24 bulan dominan anak memilki pola pemberian MPASI tidak tepat sejumlah 45 (55,6\%). Tidak sejalan dengan penelitian Damayanti yaitu sebagian besar memiliki pola MP-ASI yang baik yaitu 40 (72,7\%). Damayanti mengatakan pola pemberian MP-ASI yang baik dan tepat dapat dilihat dari usia awal pemberian MP-ASI, frekuensi pemberian, 
jumlah/porsi dan terkstur MP-ASI yang diberikan. Jika terdapat salah satu dari keempat hal tersebut yang tidak sesuai usia anak, maka dapat dikatakan pola pemberian MP-ASI tidak tepat.

Tabel 6 Distribusi Frekuensi Status Gizi Responden di Desa Sampora (n=81)

\begin{tabular}{ccc}
\hline Status Gizi & $\mathbf{n}$ & $\mathbf{\%}$ \\
\hline Normal & 56 & 69,1 \\
Tidak Normal & 25 & 30,9 \\
Total & 81 & 100 \\
\hline
\end{tabular}

Berdasarkan tabel 6 menunjukan dari 81 anak usia 6-24 bulan dominan memilki status gizi normal sejumlah 56 (69,1\%). Sejalan dengan penelitian Asweros Umbu Zogara dominan anak memilki status gizi normal sejumlah 58 (87,8\%). Status gizi normal dapat tercapai apabila tubuh mendapatkan cukup nutrisi (Adriani \& Wirjatmadi, 2014). Penelitian yang dilakukan oleh Nelfi Sarlis, menyebutkan status gizi dipengaruhi oleh pengetahuan ibu. Pengetahuan ibu yang baik mengenai gizi anak, akan membuat ibu menjadi lebih memperhatikan dalam pemberian zat gizi.

Tabel 7 Hubungan Pola Pemberian MP-ASI Dengan Status Gizi Anak (n=81)

\begin{tabular}{|c|c|c|c|c|c|c|c|c|}
\hline \multirow{3}{*}{$\begin{array}{c}\text { Pola } \\
\text { Pemberian } \\
\text { MP-ASI }\end{array}$} & \multicolumn{4}{|c|}{ Status Gizi } & \multirow{2}{*}{\multicolumn{2}{|c|}{ Total }} & \multirow{3}{*}{$\begin{array}{c}\text { OR (CI } \\
95 \%)\end{array}$} & \multirow{3}{*}{$\begin{array}{c}P \\
\text { value }\end{array}$} \\
\hline & \multicolumn{2}{|c|}{ Normal } & \multicolumn{2}{|c|}{$\begin{array}{c}\text { Tidak } \\
\text { Normal }\end{array}$} & & & & \\
\hline & $\mathrm{n}$ & $\%$ & $\mathrm{n}$ & $\%$ & $\mathrm{n}$ & $\%$ & & \\
\hline Tepat & 31 & 86,1 & 5 & 13,9 & 36 & 100 & 4,960 & \\
\hline Tidak Tepat & 25 & 55,6 & 20 & 44,4 & 45 & 100 & $(1,630-$ & 0,007 \\
\hline Total & 56 & 69,1 & 25 & 30,9 & 81 & 100 & $15,090)$ & \\
\hline
\end{tabular}

Berdasarkan tabel 7 menunjukan, banyaknya anak usia 6-24 bulan yang memiliki pola MPASI tepat yaitu $31(86,1 \%)$ berstatus gizi normal. Dari hasil analisis diperoleh terdapat hubungan bermakna antara pola pemberian MP-ASI dengan status gizi anak dengan $p$-value $0,007<0,05$ dan nilai odds ratio sebesar 4,960 yang berarti anak yang diberikan pola MP-ASI tepat beresiko 4,960 kali berstatus gizi normal dibandingkan dengan anak yang diberikan pola MP-ASI tidak tepat.

Sejalan dengan penelitian Damayanti, anak yang memiliki pola MP-ASI tepat sebanyak 38 (95\%) berstatus gizi normal dan anak yang memilki pola MP-ASI tidak tepat sebanyak 2 (13,3\%) berstatus gizi normal. Pada penelitian Damayanti juga terdapat hubungan pola pemberian makanan pendamping ASI (MP-ASI) dengan status gizi balita 6-24 bulan dengan besar p-value 0,000. MP-ASI ialah asupan makanan untuk anak 6-24 bulan. Status gizi anak dipengaruhi oleh asupan makanan yang diberikan. Damayanti berpendapat MP-ASI mengandung zat gizi untuk mencukupi nutrisi dari ASI. MP-ASI sangat dibutuhkan anak untuk memenuhi nutrisinya, karena pemberian MP-ASI nantinya akan berpengaruh pada tumbuh kembang anak. Pemberian MP-ASI harus memperhatikan beberapa hal yaitu usia awal pemberian, frekuensi, porsi dan tekstur yang diberikan.

Hasil penelitian ini masih terdapat banyak anak yang memiliki pola MP-ASI yang tidak tepat. Hal ini disebabkan karena pola MP-ASI dipengaruhi oleh beberapa faktor seperti disebutkan dalam penelitian Prita Swandari. Pendidikan adalah satu dari banyak hal yang mempengaruhi pemberian MP-ASI. Semakin tinggi pendidikan ibu, semakin mudah ibu untuk menambah wawasan mengenai pola pemberian MP-ASI yang tepat, sehingga ibu yang berpendidikan tinggi akan lebih memperhatikan dalam pemberian MP-ASI kepada anaknya.

Tabel 7 menunjukkan masih terdapat $5(13,9 \%)$ anak yang memilki pola MP-ASI tepat tetapi berstatus gizi tidak normal serta terdapat $20(44,4 \%)$ anak yang memiliki pola MP-ASI tidak tepat tetapi berstatus gizi normal. Penyebab permasalahan gizi terdiri dari beberapa faktor antara lain, konsumsi makanan, infeksi, pola asuh, lingkungan, sanitasi, tingkat pendidikan dan tingkat sosial 
ekonomi masyarkat (Wardhani, 2015). Sehingga pemberian MP-ASI saja tidak dapat menjamin anak berstatus gizi normal atau tidak, tetapi ibu juga perlu memperhatikan faktor lain yang mempengaruhi status gizi

\section{SIMPULAN}

Berdasarkan hasil analisa yang telah dilakukan terkait dengan hubungan pola pemberian makanan pendamping air susu ibu (MP-ASI) terhadap status gizi anak di Wilayah Kerja Puskesmas Suradita Kabupaten Tangerang, yang dilakukan pada 81 responden maka dapat disimpulkan bahwa terdapat hubungan bermakna antara pola pemberian MP-ASI dengan status gizi anak di Wilayah Kerja Puskesmas Suradita Kabupaten Tangerang.

\section{SARAN}

Proporsi anak yang memiliki pola MP-ASI tidak tepat masih lebih banyak dibandingkan anak yang memiliki pola pemberian MP-ASI yang tepat, diharapkan kepala puskesmas dapat membuat konseling bagi orang tua dalam pemberian MP-ASI untuk mencegah status gizi yang tidak normal.

Peneliti menyarankan bidan dapat lebih memotivasi kader untuk lebih aktif mengajak ibu yang memilki anak bayi untuk melakukan penimbangan secara rutin setiap bulan dan memantau dalam pemberian MP-ASI untuk mencegah status gizi yang tidak normal. Pada penelitian selanjutnya disarankan untuk mengukur juga asupan energi yang diberikan dalam MP-ASI.

\section{DAFTAR PUSTAKA}

Adriani, M. D. dan Wirjatmadi, B. prof. dr. (2014) Gizi dan Kesehatan Balita. 1st edn. Jakarta: Kencana Prenadamedia Group. Tersedia di: https:/ / books.google.co.id/books?id=mfpDDwAAQBAJ\&pg=PA116\&dq=indeks+antropom etri\&hl=id\&sa=X\&ved=0ahUKEwi19suYu_TnAhWgILcAHdOUA4IQ6AEISzAE\#v=onepage $\& \mathrm{q}=$ indeks antropometri\&f$=$ false.

Damayanti dan Fatonah, S. (2016) 'Hubungan Pola Pemberian Makanan Pendamping ASI dengan Status Gizi Balita Usia 6-24 Bulan', Jurnal Ilmiah Keperawatan Sai Betik, XII(2), hal. 257-263.

Herlistia, B. H. R. dan Muniroh, L. (2016) 'Hubungan Pemberian Makanan Pendamping Asi (MpAsi) Dan Sanitasi Rumah Dengan Status Gizi Bayi Keluarga Miskin Perkotaan', Media Gizi Indonesia, 10(1), hal. 76-83. doi: 10.20473/MGI.V10I1.76-83.

Heryanto, E. (2017) 'Faktor-Faktor yang Berhubungan dengan Pemberian Makanan Pendamping ASI Dini', AISYAH: Jurnal Ilmu Kesehatan, 2(2), hal. 141-152. Tersedia di: http://ejournal.stikesaisyah.ac.id/index.php/jika/ (Diakses pada: 19 Februari 2020).

IDAI (2018) Pemberian Makanan Pendamping Air Susu Ibu (MPASI). Jakarta: UUK Nutrisi dan Penyakit Metabolik.

Ismawati (2020) Porsi ASI Untuk Bayi Yang Baru Mulai MPASI, Ibupedia.com. Tersedia di: https://www.ibupedia.com/artikel/balita/porsi-asi-untuk-untuk-bayi-yang-baru-mulaimpasi.

Kemenkes (2014) Kondisi Pencapaian Program Kesehatan Anak Indonesia. Jakarta: InfoDATIN.

Maria, I. (2016) Hubungan Pemberian ASI Eksklusif dengan Status Gizi Bayi Usia 6-12 Bulan di Polindes Patranrejo Berbek Nganjuk, Hospital Majapahit. Tersedia di: http://ejournal.stikesmajapahit.ac.id/index.php/HM/article/view/117 (Diakses pada: 19 Februari 2020).

Sagala, M. (2018) 'Correlation Between Parenting Pattern and Mpasi-Giving Pattern To Nutritional Statusof Infants Aged 6-12 Months in Mekargalih Village', International Conference on Public Health, 3, hal. 134-142. doi: 10.17501/icoph.2017.3217.

Saputri, F. dan Kusumastuti (2019) 'Penerapan Penyuluhan tentang MP ASI terhadap Praktek Pemberian MP ASI 4 Bintang pada Bayi Umur 6-12 Bulan di BPM Jemanis Kabupaten Kebumen', University Research Colloqium, hal. 556-564.

Sarlis, N. dan Ivanna, C. N. (2016) 'Faktor Berhubungan dengan Status Gizi Balita di Puskesmas Sidomulyo Pekanbaru Tahun 2016', Jurnal Endurance, 3(1), p. 146. doi: 10.22216/jen.v3i1.2074. 
Subandra, Y., Zuhairini, Y. dan Djais, J. (2018) 'Hubungan pemberian ASI Eksklusif dan Makanan Pendamping ASI terhadap Balita Pendek Usia 2 sampai 5 tahun di Kecamatan Jatinangor', Jurnal Sistem Kesehatan, 3(3), hal. 142-148. doi: 10.24198/jsk.v3i3.16990.

Sunarsih, T. dan Shanti, E. F. A. (2019) 'Pemberdayaan Masyarakat Melalui Manager Komunitas sebagai Upaya Peningkatan Kesehatan Ibu dan Anak', Jurnal Pengabdian 'Dharma Bakti', 2(1), hal. 20-27.

Swandari, P. dkk. (2017) Karakteristik Ibu Dalam Pemberian Makanan Pendamping ASI (MPASI) Dini Terhadap Status Gizi Balita Usia 6-24 Bulan di Wilayah Kerja Puskesmas Umbulharjo I Kota Yogyakarta Tahun 2017, Public Health Perspective Journal. Tersedia di: http://journal.unnes.ac.id/sju/index.php/phpj (Diakses pada: 12 Februari 2020).

UNICEF (2019) 'Children, food and nutrition world', hal. 2-9.

Waliyo, E., Marlenywati, M. dan Nurseha, N. (2017) 'Hubungan Pengetahuan Gizi dan Pola Pemberian Makanan Pendamping Asi Terhadap Status Gizi pada Umur 6-59 Bulan Di Wilayah Kerja Puskesmas Selalong Kecamatan Sekadau Hilir Kabupaten Sekadau', Jurnal Kedokteran dan Kesehatan, 13(1), p. 61. doi: 10.24853/jkk.13.1.61-70.

Wardhani, G. K. (2015) 'Nutritional Status of Infants 6-24 Months in the Setabelan', Jurnal Ilmiah Kesehatan Media Husada, 7(2), hal. 71-78.

WHO (2018) Infant and young child feeding. Tersedia di: https://www.who.int/news-room/factsheets/detail/infant-and-young-child-feeding.

WHO (2020) Breastfeeding. Tersedia di: https://www.who.int/healthtopics/breastfeeding\#tab=tab_1.

WHO (2020) Complementary Teeding. Ti: https://www.who.int/nutrition/topics/complementary_feeding/en/.

Widiastuti, D. P., Novayelinda, R. dan Woferst, R. (2018) 'Hubungan Usia Awal Pemberian Makanan Pendamping Asi (MP-ASI) dengan Status Antropometri Pada Anak Usia 9-12 Bulan', JOM FKp, 5(2), hal. 618-625.

Yuliarti, N. (2010) Keajaiban ASI Makanan Terbaik untuk Kesehatan, Kecerdasan dan Kelincahan si Kecil. Yogyakarta: Andi Offset. Tersedia di: https:/ / books.google.co.id/ books?id=q92ckECrZekC\&pg=PA7\&dq=kandungan+asi\&hl=id\& $\mathrm{sa}=$ X\&ved=0ahUKEwj8yav9vP7nAhWd7HMBHSJQAvUQ6AEIKTAA\#v=onepage $\& \mathrm{q}=\mathrm{kandu}$ ngan asi\&f $=$ false.

Zogara, A. U. (2020) 'Pemberian Makanan Pendamping ASI (MPASI) dan Status Gizi Balita di Kelurahan Tuak Daun Merah', CHMK Health Journal, 4, hal. 112-117. 